\title{
Bufotenine, a tryptophan-derived alkaloid, suppresses the symptoms and increases the survival rate of rabies-infected mice: the development of a pharmacological approach for rabies treatment
}

\author{
Hugo Vigerelli ${ }^{1}$, Juliana M. Sciani ${ }^{1,5}$, Patricia M. C. Pereira ${ }^{1}$, Aline A. Lavezo ${ }^{2}$, Andrea C. R. Silva ${ }^{3}$, \\ Rita C. O. Collaço ${ }^{4}$, Thalita Rocha ${ }^{5}$, Thais C. Bueno ${ }^{5}$, Daniel C. Pimenta ${ }^{1, *}$ (D) \\ ${ }^{1}$ Laboratory of Biochemistry and Biophysics, Butantan Institute, São Paulo, SP, Brazil. \\ ${ }^{2}$ Laboratory of Biological Quality Control in vivo, Butantan Institute, São Paulo, SP, Brazil. \\ ${ }^{3}$ Laboratory of Rabies Diagnostic, Serology, Pasteur Institute, São Paulo, Brazil \\ ${ }^{4}$ Department of Pharmacology, State University of Campinas (Unicamp), Campinas, SP, Brazil. \\ ${ }^{5}$ Multidisciplinary Research Laboratory, São Francisco University, Bragança Paulista, SP, Brazil.
}

\section{Keywords:}

Rabies

Rabies therapy

Bufotenine

\begin{abstract}
Background: Between 40,000-70,000 people die yearly of rabies, an incurable disease. Besides post-bite vaccination, no treatment is available for it.

Methods: First, virus dilution for antiviral effects in mice was determined. Then, animals were treated as follows: control $(\mathrm{NaCl} 250 \mu \mathrm{L} /$ animal/day); bufotenine $(0.63$, 1.05 and $2.1 \mathrm{mg}$ in $250 \mu \mathrm{L}$ of $\mathrm{NaCl} / \mathrm{animal} /$ day); rabies $\left(10^{-6,82} \mathrm{CVS}\right.$ dilution); and test $\left(10^{-6,82} \mathrm{CVS}\right.$ dilution and bufotenine, in the above-mentioned doses). Animals were observed daily for 21 days or until the $3^{\text {rd }}$ stage of rabies infection. Twitch-tension and liposome studies were applied to understand the possible interaction of bufotenine with receptors, particularly acetylcholine.

Results: Bufotenine was able to increase the survival rate of intracerebrally virus-infected mice from 15 to $40 \%$. Bufotenine did not seem to interfere with the acetylcholine response in the skeletal muscle, indicating that its mechanism of action is not blocking the virus entrance due to $\mathrm{nAChR}$ antagonism. By analyzing liposomes, we could observe that bufotenine did not passively penetrates cell membranes, indicating the necessity of complementary structures to cell penetration.

Conclusions: Bufotenine is a promising candidate for drug development. After further chemical modification, it might be possible to dissociate minor side effects, increase efficiency, efficacy and pharmacokinetics, yielding a true anti-rabies drug.
\end{abstract}

* Correspondence: dcpimenta@butantan.gov.br http://dx.doi.org/10.1590/1678-9199-JVATITD-2019-0050 Received: 19 august 2019; Accepted: 19 december 2019; Published online: 03 february 2020 


\section{Background}

Rabies is a disease that occurs in more than 150 countries, where 3 billion people are exposed to infection and 40,000-70,000 people die every year [1-3]. It is a $100 \%$ vaccine-preventable disease and in over $99 \%$ of the cases, the virus is transmitted to humans by domestic dogs [1]. The WHO fact-sheet on rabies states that "Globally, rabies deaths are rarely reported and children between the ages of 5-14 years are frequent victims. Treating a rabies exposure, where the average cost of rabies post-exposure prophylaxis is US\$ 40 in Africa, and US\$ 49 in Asia, can be a catastrophic financial burden on affected families whose average daily income is around US\$ 1-2 per person".

There are only ten reported cases of rabies cure in the literature that do not lack scientific evidence, and only three of them had completely recovered or suffered mild sequelae [4-14]. There is constant research on new, more effective and less expensive agents displaying potential antiviral activities on rabies [15-17]. However, in spite of the knowledge gathered on aspects of the disease and the host immune response, no antiviral compound with reproducible activity in animal models for rabies has been found [18].

Taking this into account, we have performed the bio-monitored screening of the amphibian skin secretion targeting anti-rabies molecules, based on that one possible mechanism of the virus penetration in mammal cells is via the nicotinic acetylcholine receptor (nAChR) [19], and some amphibians secrete a myriad of alkaloids in their skin, which would bind these receptors [20]. We have successfully described that bufotenine inhibits rabies virus infection in mammalian cells in a dose and time-dependent manner [21]. Moreover, bufotenine acted synergistically with a synthetic tetrapeptide derived from the natural ocellatin-F1 [22], similar to the rabies virus glycoprotein region associated with the viral cell penetration [23]. As bufotenine's actual mechanism of action is still under investigation, the safety of the chronic administration on mice was assessed [24]. Here, behavioral and biological aspects were observed, in order to study the bufotenine as a possible interfering agent in the process of rabies virus infection in vivo.

\section{Methods}

\section{Ethics statement}

All in vivo experiments were approved by the Ethics Committee on Animal Use of the Butantan Institute (CEUAIB - 9532050216).

\section{Reagents}

All reagents were of analytical grade and were purchased from Sigma Aldrich (USA), unless otherwise stated.

\section{Bufotenine}

Anadenanthera colubrina seeds were obtained from the legitimate supplier Arbocenter Comércio de Sementes Ltda, Birigui, São Paulo, Brazil (batch 0019). Bufotenine was purified as previously described [21].

\section{Mice, cells and viruses}

Swiss mice (Mus musculus), both male and female (21 g) were employed in antiviral experiments and male mice $(30 \mathrm{~g})$, in the twitch-tension studies. Animals were housed (3-6 per cage), at room temperature $\left(22 \pm 2^{\circ} \mathrm{C}\right)$ and $12: 12 \mathrm{~h}$ light:dark cycle, with free access to food and water.

Mouse neuroblastoma (N2A) cell line (ATCC $\left.{ }^{\circledR} \mathrm{CCL}\right)$ were cultured in MEM-10 medium, with Earle's balanced salts and supplementation of essential amino acids, at $37^{\circ} \mathrm{C}$, in a humidified $5 \% \mathrm{CO}_{2}$ atmosphere, until the formation of the cell monolayer.

Three strains of street rabies viruses circulating in Brazil were isolated from central nervous system samples of naturally infected animals (a dog, the insectivorous bat Eptesicus furinalis and a bovine that was infected by the hematophagous bat Desmodus rotundus) positively diagnosed for such strains through genome sequencing performed in the Virology Laboratory, Pasteur Institute, São Paulo, Brazil [25]. Rabies virus challenge virus standard (CVS/31 batch 31/3\#2/IB-6) were also used to determine the antiviral activity.

\section{Cytotoxicity of bufotenine in N2A cells}

The cytotoxicity evaluation of bufotenine was performed by the MTT [3-(4,5-dimethylthiazol-2-yl)-2,5-diphenyltetrazolium bromide] method, according to Takeuchi et al. [26] and Mosmann [27], with slight modifications. Briefly, N2A cells (5 $\times 10^{5}$ cells/well) were deposited in 96-well microtiter plates and incubated with $50 \mu \mathrm{L}$ (constant volume) of different bufotenine concentrations (from 1 to $8 \mathrm{mg} / \mathrm{mL}$ ) diluted in MEM-10. Negative control was MEM-10. After 96 hours at $37^{\circ} \mathrm{C}$, under a humidified $5 \% \mathrm{CO}_{2}$ atmosphere, the medium was removed and $50 \mu \mathrm{L} 1 \mathrm{mg} \cdot \mathrm{mL}^{-1} \mathrm{MTT}$, in MEM-10, was added, following a four-hour incubation period. Next, the MTT solution was removed and $100 \mu \mathrm{L}$ dimethyl sulfoxide (DMSO) was added to each well. After gentle shaking of the plates, the absorbance was measured (Molecular Devices ${ }^{\varpi}$, SpectraMax M2) at $540 \mathrm{~nm}$. The cytotoxic concentration $\left(\mathrm{CC}_{50}\right)$ value was defined as bufotenine concentration able to reduce the MTT assay absorbance of treated cells by $50 \%$, when compared to the control, untreated cells.

\section{N2A cells fluorescence inhibition test}

This test was performed according to a previous study [28], with modifications. Briefly, different rabies virus strains suspensions were deposited on 96-well microtiter plates that were kept on ice bath during sample preparation. Then, $110 \mu \mathrm{L}$ MEM-10 and $50 \mu \mathrm{L}$ bufotenine $(1.5$ or $0.75 \mathrm{mg} / \mathrm{mL})$ were added. Samples were homogenized and, following removal from ice, $100 \mu \mathrm{L}$ of $\mathrm{N} 2 \mathrm{~A}$ cells $\left(5 \times 10^{5}\right)$ were added. After a 96 -hour incubation period at $37^{\circ} \mathrm{C}$, under a humidified $5 \% \mathrm{CO}_{2}$ atmosphere, the supernatants were collected for subsequent virus titration. Microplates were returned to ice. Cells were fixed with cold $80 \%$ acetone addition. After 15 minutes, the microplates were emptied by inversion and dried at $37^{\circ} \mathrm{C}[29,30]$.

Viral presence in the cultured was immunologically evaluated $-40 \mu \mathrm{L}$ of an optimal dilution antirabies fluorescent conjugate 
was incubated for $1 \mathrm{~h}$ [31]. Later, the plates were washed with PBS and viewed under fluorescence microscopy (Leica DMIL, 100x magnification). Infection inhibition was determined according to the fluorescence intensity displayed by the cell monolayer, in comparison to the negative control (no bufotenine). The supernatant virus titers were determined by plate assay [29, 30] adapted to N2A cells and expressed as-log TCID 50/mL, using the Spearman-Karber analysis.

\section{In vivo experiments}

The in vivo experiments, according to the $\mathrm{WHO}$ procedures for rabies (observation of infected animals for 21 consecutive days and monitoring of symptoms development and survival rate) [32] were divided into two cycles; and each and all experimental groups contained ten animals. Cycle 1 was necessary to establish the best virus dilution to evaluate antiviral effects. It consisted of the following treatments:

- control group: subcutaneous (SC) inoculation of $\mathrm{NaCl} 0.9 \%$, $250 \mu \mathrm{L} /$ animal/day;

- bufotenine group: SC inoculation of $0.63 \mathrm{mg}$ bufotenine, in $250 \mu \mathrm{L} \mathrm{NaCl} /$ animal/day;

- rabies group: (intracerebral inoculation route) for four dilutions of the CVS virus - $10^{-5.32}$ (corresponding to the challenge dose of approximately $30 \mathrm{LD}_{50}$ ), $10^{-6.32}$ (corresponding to $3 \mathrm{LD}_{50}$ ), $10^{-6.82}$ (corresponding to $1.35 \mathrm{LD}_{50}$ ) and $10^{-7.32}$ (corresponding to $0.3 \mathrm{LD}_{50}$ );

- bufotenine-treated group: mice inoculated with the same four dilutions of the CVS virus and treated with bufotenine $(0.63 \mathrm{mg} / 250 \mu \mathrm{L} \mathrm{NaCl})$.

Cycle 2, on the other hand, was necessary to establish the best bufotenine dose to evaluate the antiviral effects. It consisted of the following treatments:

- control group: SC inoculation of $\mathrm{NaCl} 250 \mu \mathrm{L} / \mathrm{animal} / \mathrm{day}$;

- bufotenine group: subcutaneous inoculation of $0.63,1.05$ and $2.1 \mathrm{mg}$ in $250 \mu \mathrm{L}$ of $\mathrm{NaCl} / \mathrm{animal} /$ day;

- rabies group: intracerebral inoculation route with CVS dilution of $10^{-6,82}$;

- treatment group: mice inoculated with the same CVS dilution and treated with each bufotenine dose.

The progression evaluation of infected animals' symptoms was divided into three stages. The first stage consisted onset of hunchback, prostration and piloerection. Although these signs are not specific to rabies, they indicate that the animal is ill and that its welfare is compromised. In the second stage the animal shows slow or circular movements, towards a single direction. These are the first clinical indicators of neurological disorders. In the third stage, the animal presents unstable movements, tremors and/or convulsions. These symptoms can be aroused when provoking the animal with tweezers. These neurological signs clearly indicate rabies infection. Animals were observed daily, for 21 days, or until the development of the third stage of rabies, when the animals were euthanized, avoiding the slow, progressive and irreversible animal suffering caused by the infection.

\section{Experiments with liposomes}

Liposomes were obtained and analyzed as described by Sciani et al. [33]. Briefly, liposomes $(10 \mu \mathrm{L})$ and bufotenine $(10 \mu \mathrm{g} / 10$ $\mu \mathrm{L})$ were separately analyzed for retention time determination. Next, bufotenine and liposomes were incubated $(20 \mu \mathrm{L}, 1: 1$ $\mathrm{V} / \mathrm{V}$ ) for 10 minutes at room temperature, and the mixture was analyzed under the same conditions. The liposome peak was collected and lysed with $50 \%$ acetonitrile containing $0.1 \%$ formic acid. This solution was then sonicated and centrifuged for 10 minutes at $10840 \mathrm{xg}$ at $4^{\circ} \mathrm{C}$. The supernatant was analyzed by electrospray-ion trap-time of flight (ESI-IT-TOF) (Shimadzu Co., Japan) equipped with binary ultra-fast liquid chromatography system (UFLC) (20A Prominence, Shimadzu Co., Japan), in order to identify bufotenine inside the liposomes.

\section{Phrenic nerve-diaphragm muscle (PND) preparation}

Mice were euthanized with an overdose of isoflurane (via inhalation). The hemidiaphragms and corresponding phrenic nerves were carefully removed and mounted under a tension of 5 $\mathrm{g}$ in $5 \mathrm{~mL}$ organ baths containing Tyrode solution (composition in $\mathrm{nM}: \mathrm{NaCl} 137, \mathrm{KCl} 2.7, \mathrm{CaCl}_{2} 1.8, \mathrm{MgCl}_{2} 0.49, \mathrm{NaH}_{2} \mathrm{PO}_{4} 0.42$, $\mathrm{NaHCO}_{3} 11.9$ and glucose 11.1) gassed with $95 \% \mathrm{O}_{2}$ and $5 \% \mathrm{CO}_{2}$ at $37^{\circ} \mathrm{C}$. The muscles were indirectly stimulated (nerve-evoked contractions; $0.1 \mathrm{~Hz}, 0.2 \mathrm{~ms}$, supramaximal voltage; Grass S48 stimulator). The resulting muscle tension was recorded using a force displacement transducer (BG 25 GM Kulite) coupled to a Gould RS 3400 recorder. The preparations were allowed to stabilize for at least 15 minutes before the addition of bufotenine (21 and $210 \mu \mathrm{g} / \mathrm{mL}$ ).

\section{Morphological analysis}

After 120 minutes of bufotenine incubation, diaphragm muscles were fixed in $10 \%$ formaldehyde overnight, dehydrated in graded ethanol $(70 \%, 80 \%, 95 \%$ and $100 \%)$, cleared in xylene and embedded in paraffin. Transversal sections (5- $\mu \mathrm{m}$ thick) were mounted on glass slides for hematoxylin-eosin (HE) staining for histological analyses. The slides were examined with a Nikon Eclipse E200 light microscope (Nikon, Japan) and the images were captured and qualitatively analyzed using NIS Elements 4.60.000 AR software.

\section{Statistical analysis}

All the results are expressed as mean \pm SEM. The $\mathrm{CC}_{50}$ of bufotenine concentration for N2A cells was calculated from concentration-effect curves, by nonlinear regression analysis, of two independent experiments, performed in triplicates. Survival curves were compared using Log-rank (Mantel-Cox) Test and/or the Gehan-Breslow-Wilcoxon Test, which attributes 
higher statistical weight to experimental points corresponding to deaths occurring at early time points [34]. The twitch-tension responses were expressed as a percentage of the basal values of each preparation, taken as $100 \%$ prior to the addition of bufotenine. Statistical comparisons were done using analysis of variance (ANOVA) followed by the Bonferroni test. All data analyses were done using Prism (GraphPad Inc., La Jolla, USA) and the significance set as: $\mathrm{ns} \mathrm{p}>0.05,{ }^{\star} \mathrm{p} \leq 0.05,{ }^{* *} \mathrm{p} \leq 0.01$.

\section{Results}

\section{N2A cells fluorescence inhibition test}

Our results show an evident infection inhibition effect against the CVS and the wild viruses (Fig. 1) and minute cytotoxic effects for the assayed concentrations $(1.5$ and $0.75 \mathrm{mg} / \mathrm{mL}$; below the $\mathrm{CC}_{50}$, Additional file 1), indicating that either virus strain is susceptible to the bufotenine infection inhibitory effect in mouse neuroblastoma (N2A) cell line.

\section{In vivo experiments}

For the standardization and optimization of in vivo experiments, we have initially determined the CVS challenge dose to be $10^{-}$ 5.32 (corresponding to $30 \mathrm{LD}_{50}$ ), able to kill $100 \%$ of the infected mice (Additional file $2 \mathrm{a}$ and $2 \mathrm{~d}$ ).

Then, bufotenine was administered SC $0.63 \mathrm{mg} / \mathrm{animal} / \mathrm{day}$, according to Fuller et al. [35] who established its toxicity to be $30 \mathrm{mg} / \mathrm{kg}$ for the murine (rat) equivalent. Considering the average mouse blood volume of $80 \mathrm{~mL} . \mathrm{kg}^{-1}, 0.63 \mathrm{mg} / \mathrm{animal}$ would correspond to $0.38 \mathrm{mg} \cdot \mathrm{mL}^{-1}$ (blood), which is $\approx 4$ times lower than the $\mathrm{IC}_{50}$ previously determined $\left(1.57 \mathrm{mg} \cdot \mathrm{mL}^{-1}\right)$ for BHK-21 cell virus infection inhibition [21].

Additionally, $10^{-6,32}, 10^{-6,82}$ and $10^{-7,32}$ CVS were assayed in order to evaluate proper virus dilution and antiviral effects (Additional files 2, 3, 4 and 5). The $10^{-6.82}$ dilution, able to kill $80-90 \%$ of the animals, was selected. Then, two more bufotenine doses were tested at this virus dilution: 1.05 and $2.1 \mathrm{mg} / \mathrm{animal} /$ day (equivalent to 50 and $100 \mathrm{mg} / \mathrm{kg}$, or 0.63 and $1.25 \mathrm{mg} \cdot \mathrm{mL}^{-1}$ )
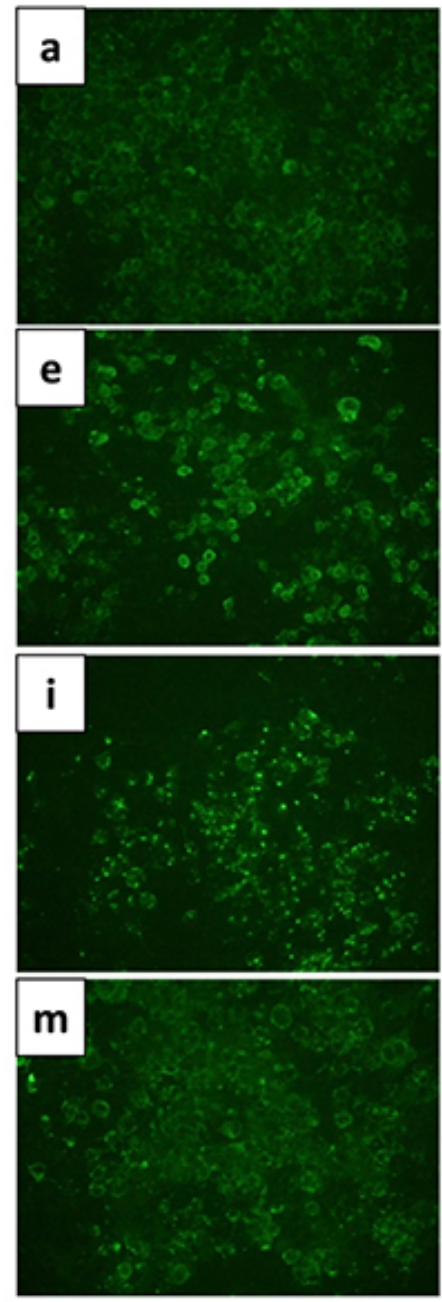
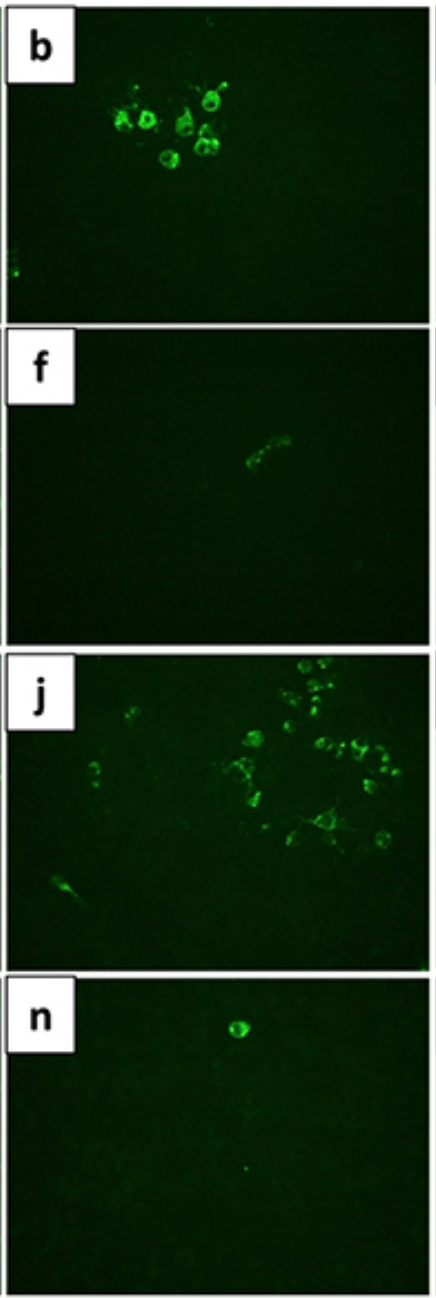
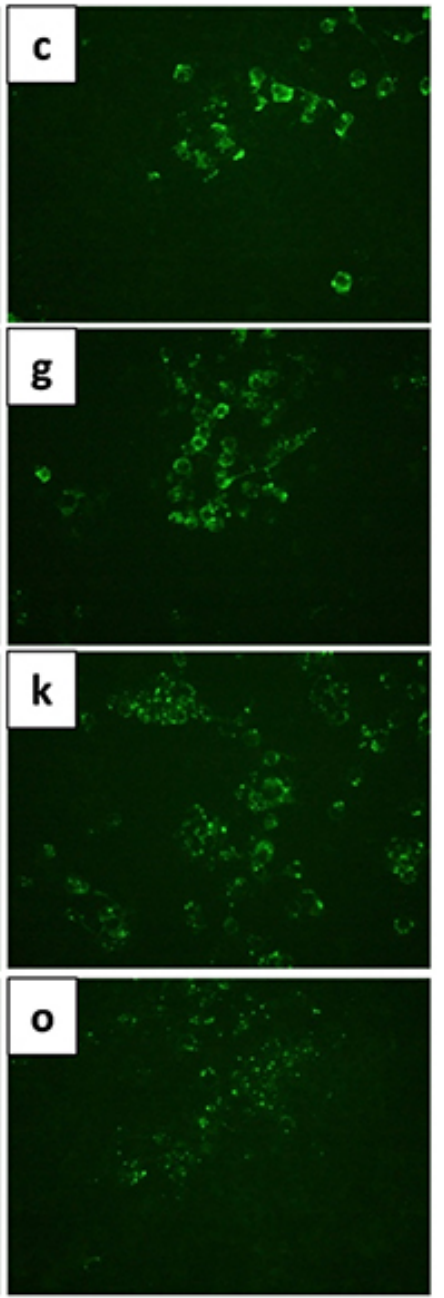
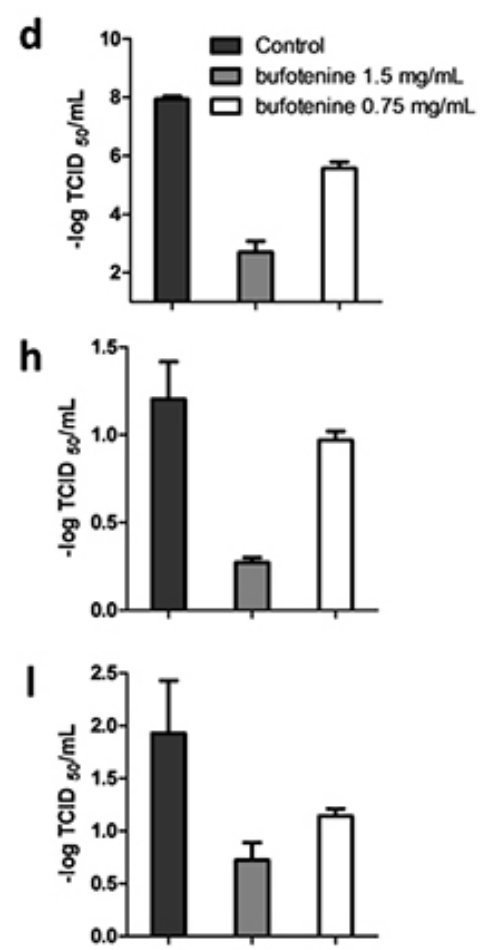

p

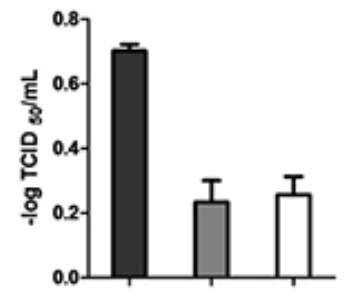

Figure 1. Bufotenine inhibits different RABV strains in N2A cells. Inhibition of challenge virus standard (CVS): (a) control; (b) bufotenine concentration of $1,5 \mathrm{mg} / \mathrm{mL}$; (c) bufotenine concentration of $0.75 \mathrm{mg} / \mathrm{mL}$; (d) supernatant virus titration. Inhibition of dog lineage RABV isolated from dog central nervous system sample: (e) control; (f) bufotenine concentration of $1.5 \mathrm{mg} / \mathrm{mL}$; (g) bufotenine concentration of $0.75 \mathrm{mg} / \mathrm{mL}$; (h) supernatant virus titration. Inhibition of Eptesicus furinalis lineage RABV isolated from bat central nervous system sample: (i) control; (j) bufotenine concentration of $1.5 \mathrm{mg} / \mathrm{mL}$; (k) bufotenine concentration of $0.75 \mathrm{mg} / \mathrm{mL}$; (I) supernatant virus titration. Inhibition of Desmodus rotundus lineage RABV isolated from bovine central nervous system sample: (m) control; (n) bufotenine concentration of $1.5 \mathrm{mg} / \mathrm{mL} ; \mathbf{( o )}$ bufotenine concentration of $0.75 \mathrm{mg} / \mathrm{mL}$; (p) supernatant virus titration. 
(Additional file 6, controls shown in Additional file 7). After all, mice infected with CVS $10^{-6,82}$ and treated with $0.63 \mathrm{mg} /$ animal/day proved to be the best model for the antiviral effect evaluation (Fig. 2). Therefore, data reported hereafter derive from such conditions (data from both experiments).

\section{Experiments with liposomes}

Our experiments showed that bufotenine cannot passively penetrate either positively or negatively charged liposomes, as shown in Figure 3. This data indicates that other cell structures, such as proteins, ion channels, receptors, or even endocytosis are important for bufotenine entrance into the cell.

\section{Phrenic nerve-diaphragm muscle (PND) and morphological analysis}

In PND preparations, bufotenine ( 21 and $210 \mu \mathrm{g} / \mathrm{mL})$ did not interfere in the contractions until $120 \mathrm{~min}$ analysis (Fig. 4). Light microscopy of control muscles (incubated for $120 \mathrm{~min}$ in Tyrode solution; Fig. 5A and 5B) and bufotenine-incubated muscles
(21 $\mu \mathrm{g} / \mathrm{mL}$; Fig. 5C and 5D) displayed normal morphology: hexagonal fibers, with peripheric nuclei, intact sarcolemma and myofilaments distribution. These results indicated that the alkaloid caused no damage to the tissue, nor to the neuromuscular junction. However, PND preparations incubated with bufotenine at a higher concentration $(210 \mu \mathrm{g} / \mathrm{mL}$, Fig. $5 \mathrm{E}-\mathrm{G})$, displayed few areas of myonecrosis, with fibers in different pathologic states, including edematous, hypercontracted, delta and ghost fibers, among normal fibers, although the neuromuscular junction was also unaffected.

\section{Discussion}

Currently, rabies laboratory research is performed with different strains of rabies viruses (RABV), namely laboratory-adapted (fixed) strains (e.g. PV and CVS) and wild-type viruses. Although fixed viruses possess the advantage of having a well-defined incubation period and predictable clinical course, these strains may have lost some of the wild-type ancestors features, such as local replication [36]. Taking this into account, we opted to use
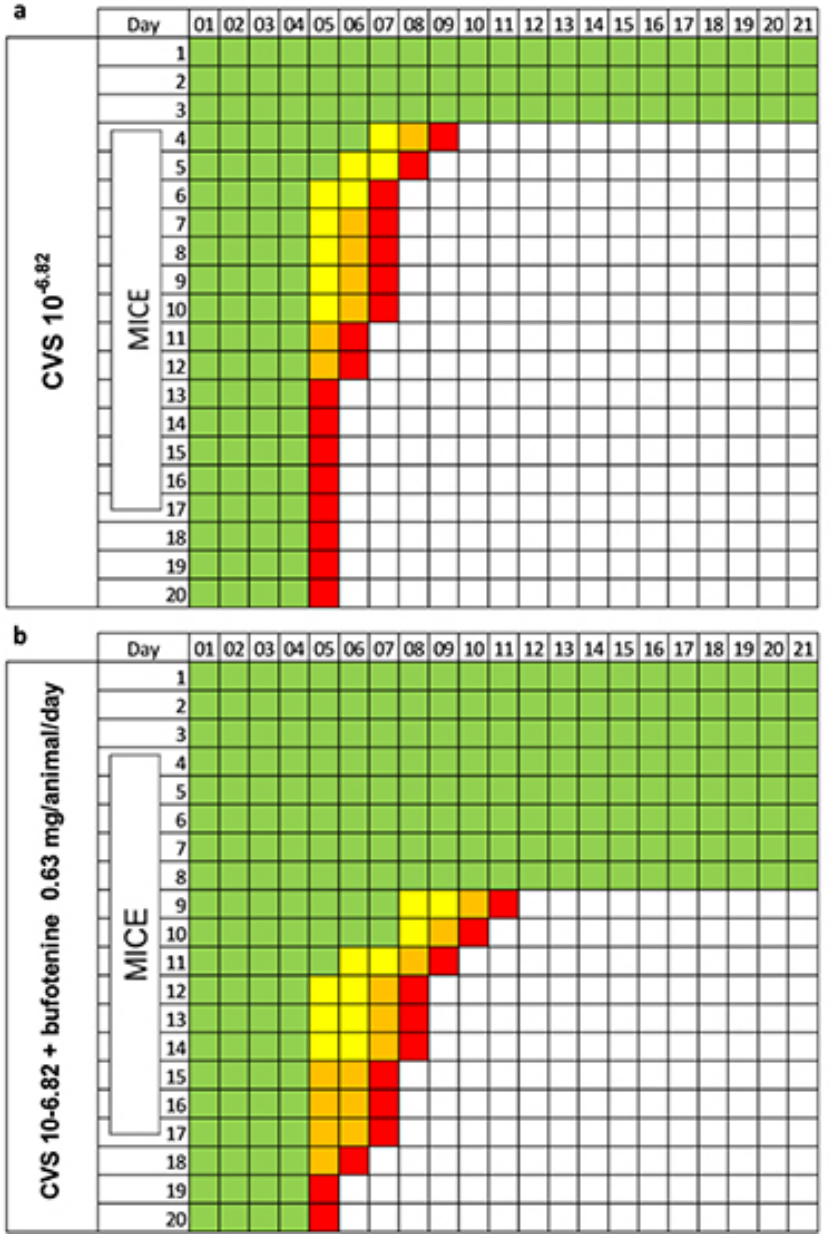

c

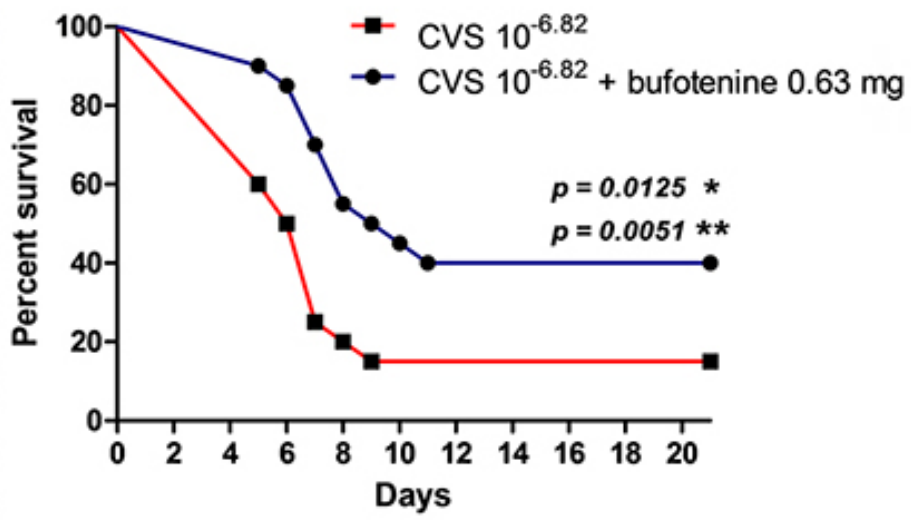

Figure 2. Onset of symptoms and percent survival of mice infected with CVS $10^{-6.22}$ (approximately $1.35 \mathrm{LD}_{50}$ ) and treated with bufotenine $0.63 \mathrm{mg} / \mathrm{animal} / \mathrm{day}$. (a) Rabies control group: symptoms onset on mice infected with CVS 10 $0^{-6.82}$; (b) treatment group: symptoms onset on mice infected with CVS $10^{-6.82}$ and treated with bufotenine $0.63 \mathrm{mg} /$ animal/day; (c) percentage survival of control group, rabies control group and treatment group. $\mathrm{p}$ value summary: * $\mathrm{p} \leq 0.05$ in Log-rank (Mantel-Cox) Test, ** $\mathrm{p} \leq 0.01$ in Gehan-Breslow-Wilcoxon Test. 
three Brazilian wild type RABV strains, first on cultured cells before the actual in vivo experiments, in order to confirm our previous results with the PV strain [21].

Interestingly, on the $5^{\text {th }}$ day of bufotenine in vivo treatment, there were still 11 healthy animals, whereas in the rabies group, there were only five (Fig. 2). Such remarkable difference was also observed for animals already displaying different stages of infection. For example, there were only two animals displaying $3^{\text {rd }}$ stage infection symptoms in the bufotenine-treated group, whilst eight animals in the rabies group had reached this phase at this same day. Furthermore, it was possible to observe major differences on the survival percent of the groups. Specifically, the bufotenine-treated group presented $90 \%$ survival rate, versus $60 \%$ of the rabies group on the $5^{\text {th }}$ day, $85 \%$ vs $50 \%$ on the $6^{\text {th }}$ day, $70 \%$ vs $25 \%$ on the $7^{\text {th }}$ day, $55 \%$ vs $20 \%$ on the $8^{\text {th }}$ day, $50 \%$ vs $15 \%$ on the $9^{\text {th }}$ day and $40 \%$ vs $15 \%$ on the $11^{\text {th }}$ day, which lasted until the $21^{\text {st }}$ and last day of experiment.

As previously observed [24], animals treated with bufotenine (and no virus) presented little histological alteration at the inoculation site and no alteration in the collected internal organs, in terms of inflammation or necrosis.

Willoughby et al. [9] reported a human survival case of a patient who developed rabies after exposure to a rabid bat, in the USA. This was the first reported survival of a patient that had not received rabies prophylaxis prior to the onset of the disease, known as the Milwaukee protocol, based on induced therapeutic coma, ketamine (anti-excitatory) and unspecific antiviral drug administration (such as ribavirin and amantadine), concomitant to patient's passive/active immunization. The patient evolved to an almost complete recovery, including extensive physical
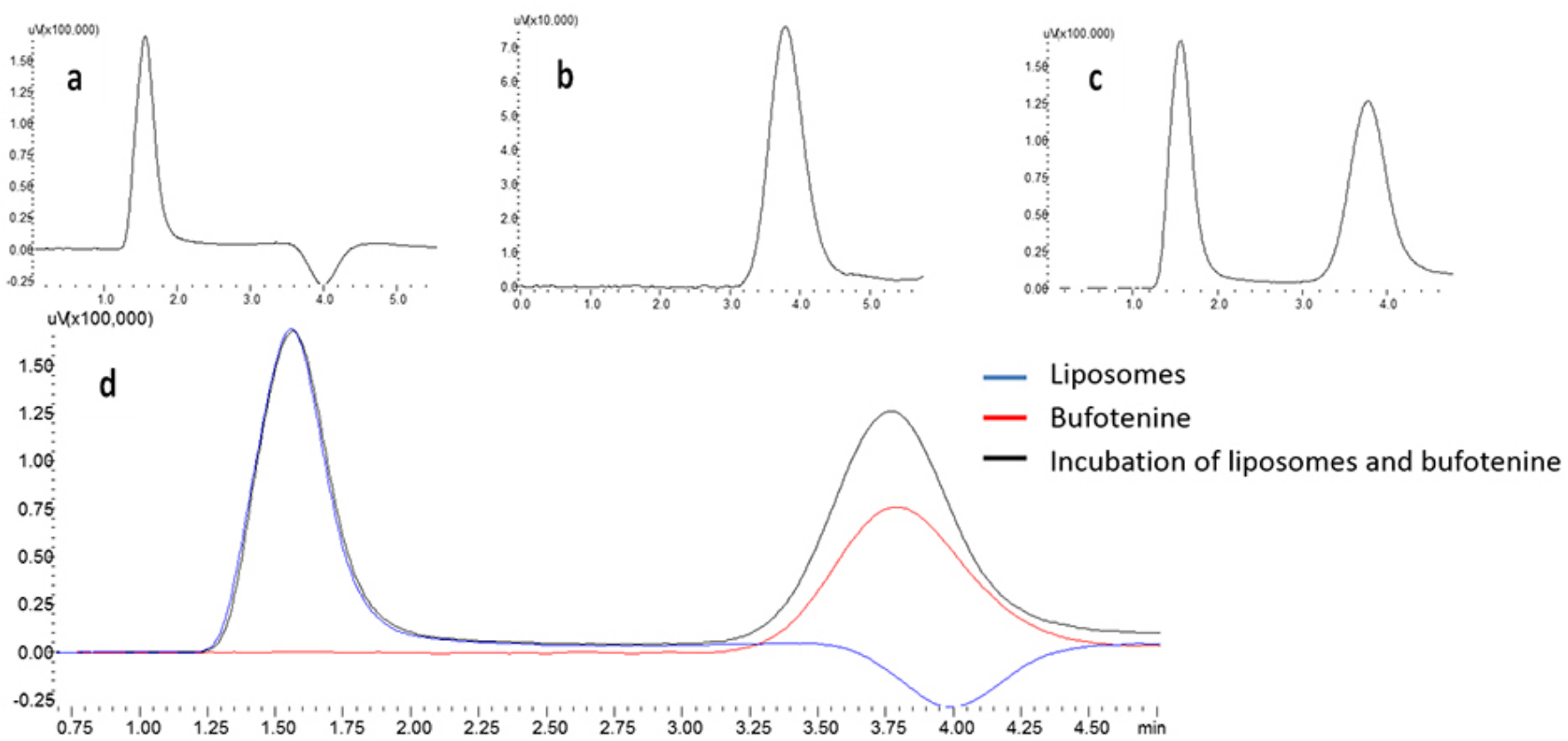

Figure 3. Analysis of bufotenine penetration in liposomes by size exclusion chromatography. (a) Positively charged liposome; (b) bufotenine; (c) incubation of liposome and bufotenine indicating no liposome penetration; (d) overlap of (a), (b) and (c).

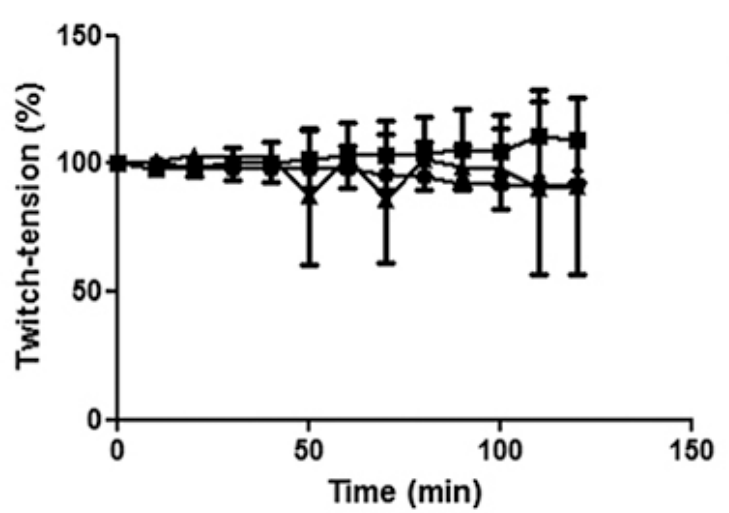

Figure 4. Representative neuromuscular response of phrenic nerve-diaphragm muscle (PND) preparation under stimulation. Bufotenine (21 and $210 \mu g / \mathrm{mL})$ was unable to induce neuromuscular blockade. The points represent the mean \pm SEM of 7-4 experiments. 


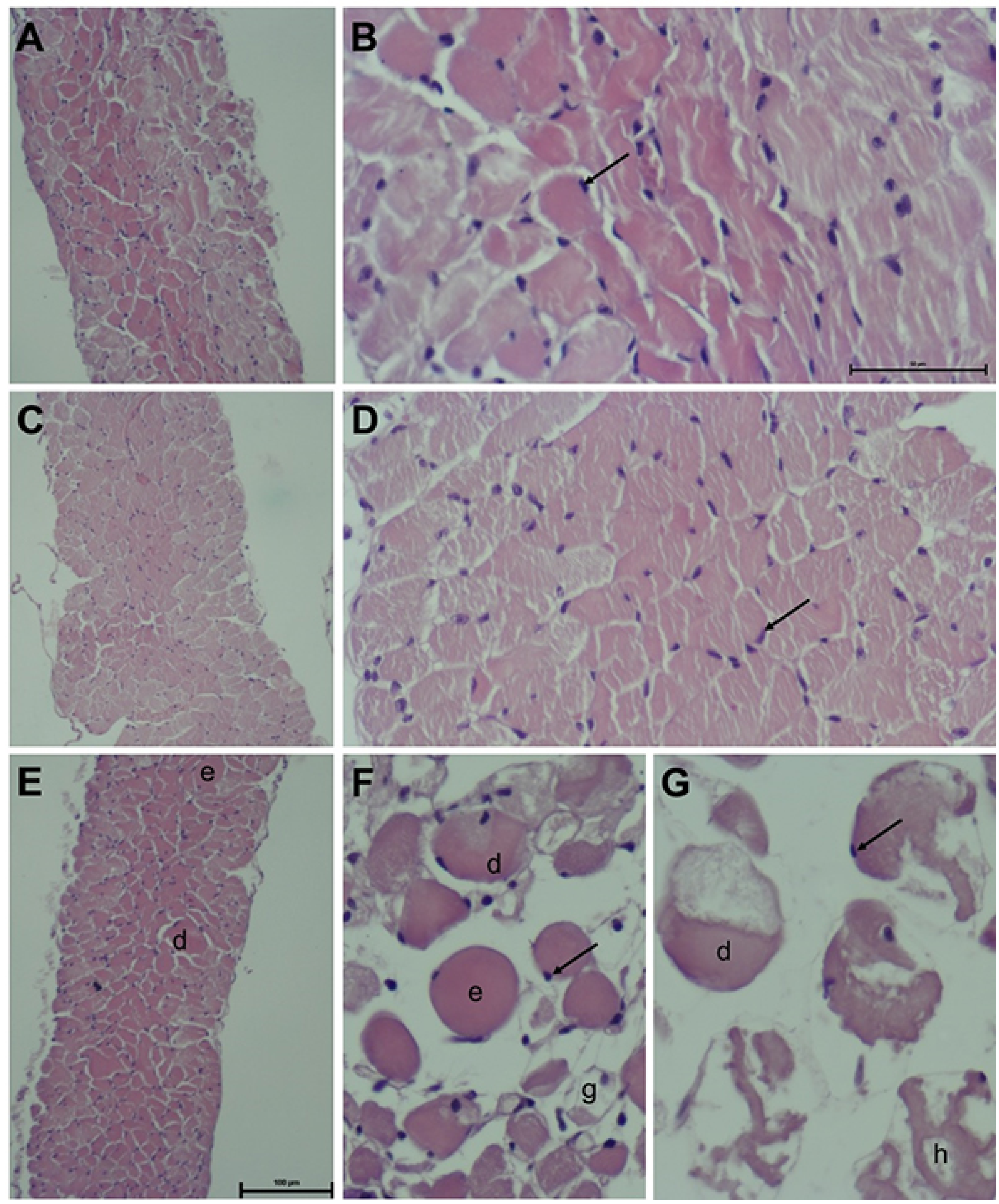

Figure 5. Histological analysis of diaphragm muscles incubated with Tyrode alone and bufotenine. (A, B) Tyrode alone, (C, D) $21 \mu \mathrm{g} / \mathrm{mL}$ of bufotenine and (E-G) $210 \mu \mathrm{g} / \mathrm{mL}$ of butotenine. Observe the normal muscle morphology in Tyrode and bufotenine at lower concentrations. However, myonecrosis can occur at $210 \mu \mathrm{g} / \mathrm{mL}$ of butotenine, as observed in (F) and (G). d: delta lesion, e: edematous fiber, h: hypercontracted fiber, g: ghost fiber. Magnification: (A, C, E) = 100x; $(B, D, F, G)=400 x$. 
and neurological rehabilitation [9]. However, several attempts to reproduce this treatment failed [37-39].

Zeiler and Jackson [40] questioned the efficiency and efficacy of this protocol by comparing the actual number of successful cases versus the detailed communications on the failed attempts $(30+)$. Moreover, these authors pity the lack of therapeutic alternatives and hope for the development of new strategies based on consolidated animal models that, according to our perspective, is what we have performed in the present study.

In order to glimpse possible bufotenine mechanisms of action, we have synthesized both positively - mimicking normal healthy cells - and negatively charged liposomes. Our experiments showed that bufotenine cannot passively penetrate either liposomes or other surface molecules, suggesting that cell receptors are necessary to facilitate bufotenine cellular entry. Cell receptors have already been described to play an important role in RABV entry, cell tropism, and spread. The neuromuscular junction acetylcholine receptor (nAChR) was the first described receptor for the RABV [41]. Later, in vitro studies showed that neural cell adhesion molecule (NCAM) and p75 neurotrophin could be involved in the virus cellular penetration [42, 43]. Thus, we have initially postulated that bufotenine would inhibit RABV penetration through competition with nAChR [21], and then we tested the alkaloid in PND preparation, which is mainly based on acetylcholine mediation.

Interestingly, we observed that the bufotenine does not directly interact with either $\mathrm{nAChR}$ or $\mathrm{mAChR}$, as no modifications in the muscular contraction could be detected under the employed experimental conditions. On the other hand, membrane proteins would be essential, according to Broughan and Wunner [44] that showed the importance of such proteins in the virus entrance into BHK-21, as well as our liposomes results demonstrated the incapacity of the bufotenine passive membrane penetration.

Furthermore, other cell-surface molecules, including sialic acid, galactose, mannose, $\mathrm{N}$-acetylglucosamine and gangliosides, have already been demonstrated to be involved in rabies virus binding to the host cells $[45,46]$. Thus, the cellular action of bufotenine remains under investigation.

\section{Conclusion}

No specific effective rabies antiviral compound does exist [18]. Bufotenine presents a novel pharmaceutical prototype to be further developed that, together with the current therapy, might prevent rabies clinical symptoms, hence supplying time for the organism's own immune response against the virus that, ultimately, would lead to a cure. It is also noteworthy to comment that, in the present study, viral load was intracerebral, whereas bufotenine treatment was subcutaneous. Moreover, virus titers were much higher (following WHO rabies protocols) than those expected to be consequence of an accident. Therefore, the $40 \%$ prevention of symptoms development reported here could be deprecated. If one mimics an accident, in which viruses would typically be injected intramuscularly at a significantly lower titer, the symptoms development prevention could be much higher, thus indicating the need for new studies aiming at the development of this molecule.

\section{Abbreviations}

$\mathrm{CC}_{50}$ : cytotoxic concentration; CVS: challenge virus standard; DMSO: dimethyl sulfoxide; ESI-IT-TOF: electrospray-ion trap-time of flight; HE: hematoxylin-eosin; nAChR: nicotinic acetylcholine receptor; NCAM: neural cell adhesion molecule; RABV: rabies viruses; SC: subcutaneous; UFLC: ultra-fast liquid chromatography system.

\section{Acknowledgments}

We are grateful to Pasteur Istitute (SP, Brazil) and Butantan Institute for the technical assistance in the conduction of the present work.

\section{Availability of data and materials}

All data generated or analyzed during this study are included in this published article (and its supplementary information files).

\section{Funding}

This work was supported by Coordination for the Improvement of Higher Education Personnel (CAPES) and Funding Authority for Studies and Projects (FINEP) - grant n. 01.09.0278.04 and 01.12.0450.03; National Council for Scientific and Technological Development (CNPq) - grant n. 406385/2018-1 to DCP; and São Paulo Research Foundation (FAPESP). DCP is a CNPq fellow researcher (grant n. 303792/2016-7).

\section{Competing interests}

The authors declare that they have no competing interests.

\section{Authors' contributions}

All the authors contributed equally in this work. HV, JMS, ACRS and DCP conceived this research and designed experiments. $\mathrm{HV}$, JMS, ACRS and DCP participated in the design and interpretation of the data. HV, JMC, PMCP, AAL, RCC, TR and TCB performed experiments and analysis. HV, JMC and DCP wrote the paper and participated in the revisions of it. All authors read and approved the final manuscript.

\section{Ethics approval}

All in vivo experiments were approved by the Ethics Committee on Animal Use of the Butantan Institute (CEUAIB - 9532050216).

\section{Consent for publication}

Not applicable. 


\section{Supplementary material}

The following online material is available for this article:

Additional file 1. Percentage of viable N2A cells after treatment with different bufotenine concentrations.

Additional file 2. Onset of symptoms and percent survival of mice infected with CVS $10^{-5.32}$ (approximately $30 \mathrm{LD}_{50}$ ) and treated with bufotenine $0.63 \mathrm{mg} / \mathrm{animal} /$ day.

Additional file 3. Onset of symptoms and percent survival of mice infected with CVS $10^{-6.32}$ (approximately $3 \mathrm{LD}_{50}$ ) and treated with bufotenine $0.63 \mathrm{mg} / \mathrm{animal} /$ day.

Additional file 4. Onset of symptoms and percent survival of mice infected with CVS $10^{-6.82}$ (approximately $1.35 \mathrm{LD}_{50}$ ) and treated with bufotenine $0.63 \mathrm{mg} / \mathrm{animal} /$ day.

Additional file 5. Onset of symptoms and percent survival of mice infected with CVS $10^{-7.32}$ (approximately $0.3 \mathrm{LD}_{50}$ ) and treated with bufotenine $0.63 \mathrm{mg} / \mathrm{animal} /$ day.

Additional file 6. Onset of symptoms and percent survival of mice infected with CVS $10^{-6.82}$ (approximately $0.3 \mathrm{LD}_{50}$ ) and treated with bufotenine $0.63,1.05$ and $2.1 \mathrm{mg} / \mathrm{animal} / \mathrm{day}$.

Additional file 7. Onset of symptoms of mice from bufotenine control groups treated with bufotenine $0.63,1.05$ and $2.1 \mathrm{mg} /$ animal/day.

\section{References}

1. World Health Organization [Internet]. Fact sheets: Rabies [cited 2019 Dec. 18]. Available from: https://www.who.int/news-room/fact-sheets/ detail/rabies.

2. Wunner WH, Briggs DJ. Rabies in the 21 st century. PLoS Negl Trop Dis 2010 Mar; 4(3):e591.

3. Knobel DL, Cleaveland S, Coleman PG, Fevre EM, Meltzer MI, Miranda $\mathrm{ME}$, et al. Re-evaluating the burden of rabies in Africa and Asia. Bull World Health Organ. 2005 May; 83(5):360-8.

4. Hattwick MA, Weis TT, Stechschulte CJ, Baer GM, Gregg MB. Recovery from rabies. A case report. Ann Intern Med. 1972 Jun;76(6):931-42.

5. Porras C, Barboza JJ, Fuenzalida E, Adaros HL, Oviedo AM, Furst J. Recovery from rabies in man. Ann Intern Med. 1976 Jun;85(1):44-8.

6. Centers for Disease $C$. Rabies in a laboratory worker-New York. MMWR Morb Mortal Wkly Rep 1977;26:183-4.

7. Alvarez L, Fajardo R, Lopez E, Pedroza R, Hemachudha T, Kamolvarin N, et al. Partial recovery from rabies in a nine-year-old boy. Pediatr Infect Dis J. 1994 Dec;13(12):1154-5.

8. Madhusudana SN, Nagaraj D, Uday M, Ratnavalli E, Kumar MV. Partial recovery from rabies in a six-year-old girl. Int J Infect Dis. 2002 Mar;6(1):856.

9. Willoughby Jr RE, Tieves KS, Hoffman GM, Ghanayem NS, Amlie-Lefond CM, Chusid MJ, et al. Survival after treatment of rabies with induction of coma. N Engl J Med. 2005 Jun 16;352(24):2508-14.

10. Hu WT, Willoughby RE Jr, Dhonau H, Mack KJ. Long-term follow-up after treatment of rabies by induction of coma. N Engl J Med. 2007 Aug 30;357(9):945-6.
11. Karahocagil MK, Akdeniz $\mathrm{H}$, Aylan O, Sunnetçiogiu M. Complete recovery from clinical rabies: case report. Turkiye Klinikleri J Med Sci. 2013;33(2):547-52.

12. Epidemiológica DdV. Protocolo para tratamento de raiva humana no Brasil. Epidemiologia e Serviços de Saúde 2009;18:385-94.

13. Galvez S, Basque M, Contreras L, Merino C, Yung V, Favi M, Willoghby $R$. Survivor of rabies encephalitis in Chile. Platform presentation at the XXIVth International Meeting on Research Advances and Rabies Control in the Americas in Toronto, Ontario, Canada on October 27, 2013.

14. de Souza A, Madhusudana SN. Survival from rabies encephalitis. J Neurol Sci. 2014 Apr 15;339(1-2):8-14.

15. Real E, Rain JC, Battaglia $V$, Jallet C, Perrin P, Tordo N, et al. Antiviral drug discovery strategy using combinatorial libraries of structurally constrained peptides. J Virol. 2004 Jul;78(14):7410-7.

16. Brandão PE. Short-interfering RNAs as antivirals against rabies. Braz J Infec Dis. 2007;11(2):224-5.

17. Lingappa UF, Wu X, Macieik A, Yu SF, Atuegbu A, Corpuz M, et al. Hostrabies virus protein-protein interactions as druggable antiviral targets. Proc Natl Acad Sci U S A. 2013 Mar 5;110(10):E861-8.

18. Smith TG, Wu X, Franka R, Rupprecht CE. Design of future rabies biologics and antiviral drugs. Adv Virus Res. 2011;79:345-63.

19. Lafon M. Rabies virus receptors. J Neurovirol. 2005 Feb;11(1):82-7.

20. Sciani JM, Angeli CB, Antoniazzi MM, Jared C, Pimenta DC. Differences and similarities among parotoid macrogland secretions in South American toads: a preliminary biochemical delineation. Sci World J. 2013;2013:937407.

21. Vigerelli H, Sciani JM, Jared C, Antoniazzi MM, Caporale GMM, Silva $A C R$, et al. Bufotenine is able to block rabies virus infection in BHK-21 cells. J Venom Anim Toxins incl Trop Dis. 2014;20:45. doi: 10.1186/16789199-20-45.

22. Cunha Neto Rdos S, Vigerelli H, Jared C, Antoniazzi MM, Chaves LB, da Silva AC, et al. Synergic effects between ocellatin-F1 and bufotenine on the inhibition of BHK-21 cellular infection by the rabies virus. J Venom Anim Toxins incl Trop Dis. 2015 Dec 2;21:50. doi: 10.1186/s40409-015-0048-1.

23. Finke $S$, Conzelmann K-K. Replication strategies of rabies virus. Virus Res. 2005 Aug;111(2):120-31.

24. Vigerelli H, Sciani JM, Eula MAC Sato LA, Antonizazzi MM, Jared C, et al. Biological effects and biodistribution of bufotenine on mice. BioMed Res Int. 2018;2018.

25. Castilho JG, Batista H, Rodrigues AC, Carnieli Jr P, Oliveira RN, Silva ACR, et al. Experimental antiviral therapy against different rabies virus lineages using transfection with anti-rabies antibodies. Reunião Internacional da Raiva nas Américas. 2012;10(2-3).

26. Takeuchi H, Baba M, Shigeta S. An application of tetrazolium (MTT) colorimetric assay for the screening of anti-herpes simplex virus compounds. J Virol Methods. 1991 Jun;33(1-2):61-71.

27. Mosmann T. Rapid colorimetric assay for cellular growth and survival: application to proliferation and cytotoxicity assays. J Immunol Methods. 1983 Dec 16;65(1-2):55-63.

28. Castilho JG, lamamoto Nogi K, Lima JYO, Scheffer K. Padronização e aplicação da técnica de isolamento do vírus da raiva em células de neuroblastoma de camundongo (N2A). Bol Epidemiol Paul. 2007;4(47):12-28.

29. Smith JS, Yager PA, Baer GM. A rapid fluorescent focus inhibition test (RFFIT) for determining rabies virus-neutralizing antibody. In: Meslin FX, Kaplan MM, Koprowski H, editors. Laboratory Techniques in Rabies. $4^{\text {th }}$ ed. Geneva: World Health Organization; 1996. p. 200-8.

30. Chaves LB, Mazutti ALC, Caporale GMM, Scheffer KC, Silva ACR. Comparision of RFFIT performed in lab-tek ${ }^{\circledR}$ and in 96-well microtitre plates. Ministério da Saúde:161.

31. Caporale GMM, Silva ACR, Peixoto ZMP, Chaves LB, Carrieri ML, Vassão RC. First production of fluorescent anti-ribonucleoproteins conjugate for diagnostic of rabies in Brazil. J Clin Lab Anal. 2009;23(1):7-13.

32. Meslin F-X, Kaplan MM, Koprowski H. Laboratory techniques in rabies. WHO. 1996.

33. Sciani JM, Vigerelli H, Costa AS, Camara DA, Luiz-de-Sá Junior P, Pimenta DC. An unexpected cell-penetrating peptide from Bothrops jararaca 
venom identified through a novel size exclusion chromatography screening. J Pept Sci. 2017;23(1):68-76.

34. Machin D, Cheung YB, Parmar M. Survival analysis: a practical approach. John Wiley \& Sons editors; 2006.

35. Fuller RW, Snoddy HD, Perry KW. Tissue distribution, metabolism and effects of bufotenine administered to rats. Neuropharmacology 1995 Jul;34(7):799-804.

36. Davis BM, Rall GF, Schnell MJ. Everything you always wanted to know about rabies virus (But were afraid to ask). Annu Rev Virol. 2015 Nov;2(1):451-71.

37. Hunter M, Johnson N, Hedderwick S, McCaughey C, Lowry K, McConville J, et al. Immunovirological correlates in human rabies treated with therapeutic coma. J Med Virol. 2010 Jul;82(7):1255-65.

38. Hemachudha T, Sunsaneewitayakul B, Desudchit T, Suankratay C, Sittipunt C, Wacharapluesadee $\mathrm{S}$, et al. Failure of therapeutic coma and ketamine for therapy of human rabies. J Neurovirol. 2006 Oct;12(5):407-9.

39. McDermid RC, Saxinger L, Lee B, Johnstone J, Gibney RT, Johnson M, et al. Human rabies encephalitis following bat exposure: failure of therapeutic coma. CMAJ. 2008 Feb 26; 178(5):557-61.
40. Zeiler FA, Jackson AC. Critical appraisal of the milwaukee protocol for rabies: this failed approach should be abandoned. Can J Neurol Sci. 2016 Jan;43(1):44-51.

41. Lentz TL, Burrage TG, Smith AL, Crick J, Tignor GH. Is the acetylcholine receptor a rabies virus receptor? Science. 1982 Jan;215(4529):182-4.

42. Thoulouze M-I, Lafage M, Schachner M, Hartmann U, Cremer H, Lafon $M$. The neural cell adhesion molecule is a receptor for rabies virus. J Virol. 1998 Sep;72(9):7181-90.

43. Tuffereau C, Bénéjean J, Blondel D, Kieffer B, Flamand A. Low-affinity nerve-growth factor receptor (P75NTR) can serve as a receptor for rabies virus. EMBO J. 1998 Dec 15;17(24):7250-9.

44. Broughan $\mathrm{JH}$, Wunner $\mathrm{WH}$. Characterization of protein involvement in rabies virus binding to BHK-21 cells. Arch Virol. 1995;140(1):75-93.

45. Superti F, Hauttecoeur B, Morelec M-J, Goldoni P, Bizzini B, Tsiang H. Involvement of gangliosides in rabies virus infection. J Gen Virol. 1986 Jan;67(Pt 1):47-56.

46. Conti C, Superti F, Tsiang H. Membrane carbohydrate requirement for rabies virus binding to chicken embryo related cells. Intervirology 1986;26(3):164-8. 